\title{
Physico-chemical Analysis and Mapping of Ground Water Quality in Residential Area of Two Different Zone of Central India
}

\author{
Arvind Prasad Dwivedi ${ }^{1}$ and Indra Prasad Tripathi ${ }^{2}$ \\ ${ }^{1}$ Lecturer, Department of Chemistry, Govt. Sanjay Gandhi Smrati Auto. P.G. College Sidhi M.P. \\ ${ }^{2}$ Professor \& Dean, Faculty of Science and Environment, M.G.C.G.V. Chitrakoot, Satna (Madhya Pradesh) \\ *Corresponding Author: Arvind Prasad Dwivedi, Lecturer, Department of Chemistry, Govt. Sanjay \\ Gandhi Smrati Auto. P.G. College Sidhi M.P.
}

\begin{abstract}
Madhya Pradesh literally means' central province' and is located in the geographic heart of India, between latitude $21.2^{\circ} \mathrm{N}-26.87^{\circ} \mathrm{N}$ and longitude $74^{\circ} 02^{\prime}-82^{\circ} 49^{\prime}$ E. In the present study forty sampling location were selected from study area. The ground water samples of residential area in two different zone of central India were collected and analyzed for various physic-chemical parameters, i.e. Temperature $24.67^{\circ} \mathrm{C}$ to 26.87 C, pH 5.9 to 8.53, Turbidity 0.10 to 4.77, Total Hardness 191.67 to $926.67 \mathrm{mg} /$, TDS 141.3 to 533.67 mg/l, DO 1.43 to 5.90, BOD 3.07to 19.17, COD 3.23 to 49.89, nitrate 0.09 to 6.47, Sulphate 0.01to186.3, Phosphate 0.001 to $2.83 \mathrm{mg} / \mathrm{l}$, in water of residential area of two different zone of central India were found. Temperature, $\mathrm{pH}$, Turbidity, nitrate and sulphate of all the samples of study area were found below the permissible limit prescribed by WHO. The results of analysis of ground water quality in residential area of two different zone of central India, it indicates that extent of pollution occurred due to the urbanization and other anthropogenic activities increased human interventions in the ground water quality.
\end{abstract}

Keywords: Physico-chemical Parameters, Ground Water, Residential Area, Central India.

\section{INTRODUCTION}

Water is the key to life. All life on the planet earth is sustained by water, though a significant portion of the earth's surface is covered with water. However the amount of fresh water which is the usable form of water is relatively a tiny portion of total water availability (Malik.et al,2014).The ground water source levels change by the regular withdrawal and hence the quality of ground water source levels change by the regular withdrawal and hence the quality of ground water reported seasonal as well as annual change in the ground water quality (Gerge et al, 1990; Rajmohan et al,1997; Singh et al, 2000; and Tripathi et al, 2013). Ground water which now account for $80 \%$ of rural and $60 \%$ of urban water supply in India is depleting at an alarming rate in several states (Gayatri et al, 2001; Dwivedi et al, 2013).

Municipal sewage discharge is one of the problems and sewage water treatment is perhaps the most challenging environmental problem in India and all over the world. Various efforts and research is being vigorously pursued to complete treatment and healthy discharge as reuse sewage water and industrial effluents. The sewage water commonly contains both solids wastes and liquids wastes generated by various human activities and also sewage water contains various trace metals and metal compounds Now a day, both surface and ground water resources are contaminated by various sources like industrial effluents, agricultural discharge and municipal waste water, associated with large amount of inorganic and organic toxic pollutants along with harmful pathogens (Okoh et al, 2002). In most of the developing countries huge debt burdens and due to population explosion and rapid urbanization, people rely heavily on water resources and polluting in the absence of better alternatives (Eo et al, 1996; Calamari et al, 1994). The developing countries like India ground water is the major source of drinking water. In arid and semiarid regions ground water plays an important role in the development and the public health of the population. The estimation showed that ground water is the source of drinking for one third of the world population. The suitability of ground water for drinking purpose is determined by its quality (Annal et al, 2014). 
The water quality parameters like $\mathrm{pH}$, Dissolved oxygen, total hardness and chemical oxygen demand have much influence on human health. The water sources with very low/high $\mathrm{pH}$ can cause ill health. Depleted dissolved oxygen will affect living marine organisms. The carbonate salts can cause hardness and they make the water unsuitable for human activities (Rao 1978). The potential health effects of high nitrate levels are diverse, including reproductive problems (Kramer et al, 1996), methemoglobinemia and cancer. Infants are especially at risk for methemoglobinemia (blue- baby syndrome), and while little conclusive evidence exists for this disorder occurring where levels are below $10 \mathrm{ppm}$, higher values found throughout the world can significantly elevate the risk (Gupta et $a l, 2000)$. Some health professionals also believe that methemoglobinemia may often be under-or misdiagnosed (Johnson and Kross 1990). Sulphate ion present in water in high concentration may cause temporary and acute effects on humans and animals, including diarrhea. It is estimated that 1.4 million child deaths occur from diarrhea every year due to poor water quality. If excess amount phosphates present in water causes risk to human beings as algae produce toxins, which damage neurological syste and causes skin disease (Santhi et al, 2014).

\subsection{Objective}

To determine the physico-chemical characteristics of various ground water samples in residential area of two different zone of central India.

\subsection{Study Area}

Madhya Pradesh is the second largest state in the country by area. It borders the state of Uttar Pradesh to the north-east, Chhattisgarh to the southeast, Maharashtra to the south, Gujarat to the west and Rajasthan to the North West.Madhya Pradesh literally means' central province' and is located in the geographic heart of India, between latitude $21.2^{\circ} \mathrm{N}-26.87^{\circ} \mathrm{N}$ and longitude $74^{0} 02^{\prime}-82^{\circ} 49^{\prime}$ E. The Central India covers the seven states of our country, it has long industrial development and also has deep cultural heritage.

\section{MATERIAL AND MethodS}

We assume Madhya Pradesh as a central India (study area) which is divided in to two zones (a) East Zone of Central India (b) West Zones of Central India. In the present study we are intended to find out the diffuse chemical pollution in Central India on the basis of a Residential area and different water bodies. We have designed twenty sampling stations district for this study in east zones i.e. Rewa, Satna, Sidhi, Singrauli, Shahdol, Umaria, Katni, Panna, Chhatarpur, Jabalpur, Mandala, Dindori, Siwani, Chhindwara, Narsinghpur, Hosangabad, Betul, Damoh, Sagar, Bhopal and twenty district in west zone i,e. Gawaliar, Shivpuri, Ashok Nagar, Datiya, Muraina, Bhind, Guna, Tikamgarh, Vidisha, Raisen, Sihora, Rajgarh, Sajapur, Dewash,Ujjain, Ratlam, Indore, Khandawa, Burhanpur and Harda of Central India. Forty water samples were collected from bore well and tube wells of two different zones of central India samples were collected in polythene bottles and analyzed for various water quality parameters as per standard procedures (AWWA, 1999). The experimental values were compared with standard values recommended by world health organization (WHO) for drinking purposes. The locations of sampling station are shown in table -1 and fig-1

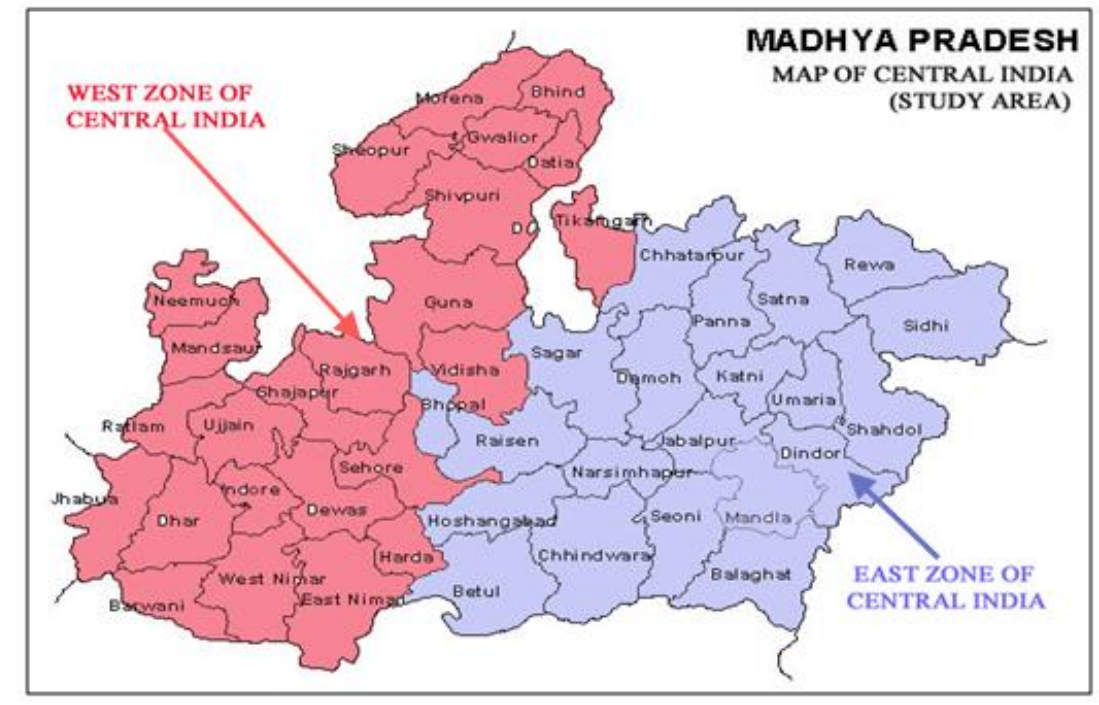


Physico-chemical Analysis and Mapping of Ground Water Quality in Residential Area of Two Different Zone of Central India

Table1. Location of sampling station in Residential Area of Two Different Zone of Central India

\begin{tabular}{|c|c|}
\hline S.N. & sampling station \\
\hline 1 & $\mathrm{R}_{1}=$ Rewa Near Bus Stand, \\
\hline 2 & $\mathrm{R}_{2}=$ Satna Near District Hospital, \\
\hline 3 & $\mathrm{R}_{3}=$ Sidhi Near Sanjay Gandhi P.G. College, \\
\hline 4 & $\mathrm{R}_{4}=$ Singrauli Near Railway station, \\
\hline 5 & $\mathrm{R}_{5}=$ Shahdol Near New Bus Stand, \\
\hline 6 & $\mathrm{R}_{6}=$ Umaria Near Govt. R.V.P.S. College, \\
\hline 7 & $\mathrm{R}_{7}=$ Katni Near Swetamber Temple, \\
\hline 8 & $\mathrm{R}_{8}=$ Panna Near Bus Stand, \\
\hline 9 & $\mathrm{R}_{9}=$ Chhatarpur Near Higher Secondary, \\
\hline 10 & $\mathrm{R}_{10}=$ Jabalpur Near S.B.I. Chhorha, \\
\hline 11 & $\mathrm{R}_{11}=$ Near R.D. P.G College Mandala, \\
\hline 12 & $\mathrm{R}_{12}=$ Dindori Near Main Post Office, \\
\hline 13 & $\mathrm{R}_{13}=$ Near Govt P.G. College Siwani, \\
\hline 14 & $\mathrm{R}_{14}=$ Chhindwara Near State Bank of India, \\
\hline 15 & $\mathrm{R}_{15}=$ Narsinghpur Near Railway Station, \\
\hline 16 & $\mathrm{R}_{16}=$ Near District Hospital Hosangabad, \\
\hline 17 & $\mathrm{R}_{17}=$ Betul Near Excellence School, \\
\hline 18 & $\mathrm{R}_{18}=$ Damoh Near Bus Stand \\
\hline 19 & $\mathrm{R}_{19}=$ Sagar Near Railway Station, \\
\hline 20 & $\mathrm{R}_{20}=$ Bhopal Near Hamidia Hospital. \\
\hline 21 & $\mathrm{R}_{21=}$ Near Gajaraja Medical College Gawaliar \\
\hline 22 & $\mathrm{R}_{22=}$ Near Tatyatope Park Shivpuri \\
\hline 23 & $\mathrm{R}_{23=}$ Ashok Nagar Near Busstand \\
\hline 24 & $\mathrm{R}_{24=}$ Datia Near Pitamabra Temple \\
\hline 25 & $\mathrm{R}_{25=}$ Muraina Near Railway Station \\
\hline 26 & $\mathrm{R}_{26=}$ Bhind ,Near Head Post Office \\
\hline 27 & $\mathrm{R}_{27}=$ Near Delhi Public School Guna \\
\hline 28 & $\mathrm{R}_{28=}$ Civil Line Tikamgarh \\
\hline 29 & $\mathrm{R}_{29=}$ Near S.A. Institute of TechnologyVidisha \\
\hline 30 & $\mathrm{R}_{30=}$ Raisen,Near Higher Secondary School \\
\hline 31 & $\mathrm{R}_{31=}$ Sihore, Near Railway Colony \\
\hline 32 & $\mathrm{R}_{32}=$ Near Anjalilal Temple ,RajgarhBiora \\
\hline 33 & R33=Near GhatiShajapur Housing Board Colony. \\
\hline 34 & $\mathrm{R}_{34}=$ Near Tilak Nagar Dewas \\
\hline 35 & $\mathrm{R}_{35}=$ Near DussehraMaidan, Ujjain \\
\hline 36 & $\mathrm{R}_{36}=$ Near Sai Baba MandirRatlam \\
\hline 37 & $\mathrm{R}_{37}=$ Near Maheswari Higher Secondary School, Indore. \\
\hline 38 & $\mathrm{R}_{38}=$ Near MalviyaColony,lalchowkiKhandwa. \\
\hline 39 & $\mathrm{R}_{39}=$ Near Bus Stand Burhanpur District \\
\hline 40 & $\mathrm{R}_{40}=$ Near HardaPolytechhnique College. \\
\hline
\end{tabular}

\section{RESULT AND DISCUSSION}

The ground water samples were analyzed some parameters like, temperature, $\mathrm{pH}$, turbidity, Total hardness, TDS, DO, BOD, COD, nitrate, sulphate and phosphate. Average physico-chemical characteristics of the ground water sample of study area were analyzed all the results are shown in table-2 and figure-2 to 12 .

\subsection{Temperature}

In the present study the temperature was found ranged between $24.67^{\circ} \mathrm{C}$ to $32.73^{\circ} \mathrm{C}$. The maximum temperature was recorded at sampling station $\left(\mathrm{R}_{14}\right)$ Datia near Pitambara Temple. Arya et al, 2011 studied assessment of underground water quality: A Case study of Jhansi city, utter Pradesh, India, reported temperature values varied between $12.0{ }^{\circ} \mathrm{C}$ to $32.0^{\circ} \mathrm{C}$.Karunakaran et al, 2009 temperature is basically important for the Chemical and biological reactions of organisms in water. The increase in temperature decrease the portable of water because of elevated temperature carbon dioxide and other volatile gases which import taste are expelled 


\section{2.pH}

The $\mathrm{pH}$ of all the water samples varied from 5.9 to 8.53 , the highest $\mathrm{pH}$ was observed 8.53 at sampling station $\left(\mathrm{R}_{7}\right)$ katni near swetambartample and the minimum value $6.90\left(\mathrm{R}_{40}\right)$ near harda polytechnique college. Shrivastava et al, 2014 studied ground water quality assessment of Birsinghpur Area, Satna District, Madhya Pradesh and PH Concentration was found ranged from 6.8 to 7.8. Gupta et al, 2010 slight alkaline range of $\mathrm{pH}$ may be explained on the basis of occurrence of limestone rocks in the surrounding of the sampling stations. Limestone changes into its soluble from, that in Calcium Bicarbonate under anaerobic Condition and provides slight alkalinity to the water.

\subsection{Turbidity}

Turbidity of water was found to be 0.10 to 4.77 NTU. All the water samples of turbidity were found below the permissible limit set by WHO. Tripathi et al, 2014 studied physico-chemical parameters and correlation coefficients of ground waters of shahdol District and turbidity was found ranged between 1.5 to $4.0 \mathrm{NTU}$. Turbidity of water is actually the expression of optical property in which the light is scattered by the particles present in the water. Clay, slit, organic matter, Phytoplankton and other microscopic organisms cause turbidity in lake water.

\subsection{Total Hardness}

In the present study the total hardness of water was observed to be 191.67 to $921.67 \mathrm{mg} / \mathrm{l}$. The highest value was found $921.67 \mathrm{mg} / \mathrm{l}$ at sampling station (R29) near S.A. Institute of Technology Vidisha. Sunita et al, 2005 Studied hydrogeo-chemistry of ground water, Gooty Area, Anantapur District, Andhra Pradesh and total hardness values were found ranged between 360 to $4040 \mathrm{mg} / \mathrm{l}$. Hardness is caused by polyvalent metallic ions dissolved in water, which in natural water are principally magnesium and calcium.

\subsection{TDS}

The results show that study area TDS values are between 141.3 to $533.67 \mathrm{mg} / \mathrm{l}$. Maximum concentration is found water samples collected from katni, which is $533.67 \mathrm{mg} / \mathrm{l}$. Minimum concentration is $141.3 \mathrm{mg} / \mathrm{l}$ found in ground water sample of khandwa. (R38).Sharma et.al, 2014 Studied a Physico-chemical Analysis and management of ground water Bodies from 20 locations of Jodhpur Districts, detected the TDS values varied from $960 \mathrm{ppm}$ to $3650 \mathrm{ppm}$. The term total dissolved solid refer mainly to the inorganic substances that are dissolved in water. The effects of TDS on drinking water quality on the levels of the individual components, excusive hardness, mineral deposition and corrosion are common properties of highly mineralized water.

\subsection{Dissolved Oxygen}

The condition in case of dissolved oxygen (DO) is slightly complicated since in complicated since in contrast to other pollutants; the quality of water is enhanced if it contains more oxygen. An ideal DO value of $5.0 \mathrm{mg} / \mathrm{l}$ is the standard for drinking water. In study area at has been found between the ranges of 1.43 to $5.90 \mathrm{mg} / \mathrm{l}$. Maximum concentration is found in ground water samples collected from Sihore $\left(\mathrm{R}_{31}\right)$ is $5.90 \mathrm{mg} / \mathrm{l}$. Tripathi et al, 2015 studied Quality and assessment of ground water in Satna, Madhya Pradesh, reported the D.O. values varied from3.90 to $5.92 \mathrm{mg} / \mathrm{l}$.

\subsection{Biochemical Oxygen Demand}

Biochemical oxygen demand varied from 3.07 to $19.17 \mathrm{mg} / \mathrm{l}$. Maximum BOD was found (919.17 $\mathrm{mg} / \mathrm{l})$ at sampling station $\left(\mathrm{R}_{31}\right)$ Sihore, Near Railway colony. Values of BOD at sampling station $\mathrm{R}_{2}$ (7.43), $\mathrm{R}_{4}(10.73), \mathrm{R}_{9}(6.27), \mathrm{R}_{16}$ (6.33), $\mathrm{R}_{18}(6.43), \mathrm{R}_{21}$ (15.17), $\mathrm{R}_{22}$ (9.30), $\mathrm{R}_{23}$ (13.67), $\mathrm{R}_{24}$ (11.23), R25 (8.43), R26 (7.30), R27 (18.83), R29 (6.33), R30 (9.77), R31(19.17) R35 (6.63), R37 (6.80) and $\mathrm{R} 38$ (6.3) $\mathrm{mg} / \mathrm{l}$ are higher than the permissible limit prescribed by WHO as $6.0 \mathrm{mg} / \mathrm{l}$. Dwivedi et al, 2016 studied Quality of Ground Water Used for Drinking in Orai, District- Jalaun, Uttar Pradeshand reported the BOD Values varied from 2.9 to13.8 mg/l.BOD refers the oxygen used by the microorganism in the aerobic oxidation of organic matter. Therefore with the increase in the amount of organic matter in the water the BOD increases.

\subsection{Chemical Oxygen Demand}

The chemical oxygen demand was found ranged between 3.23 to $49.87 \mathrm{mg} / \mathrm{l}$. COD value at sampling station $\mathrm{R}_{8}(12.83), \mathrm{R}_{21}$ (37.0), $\mathrm{R}_{22}(18.75), \mathrm{R}_{23}$ (11.50), $\mathrm{R}_{24}$ (34.97), $\mathrm{R}_{25}$ (49.87), $\mathrm{R}_{27}(27.30), \mathrm{R}_{28}$ (14. 
17), $R_{29}$ (46.37), $R_{30}$ (32.90), $R_{32}$ (31.80), $R_{33}$ (15.27), $R_{35}$ (19.90), $R_{36}(12.50), R_{37}(11.37)$, and $R_{38}$ (10.33) $\mathrm{mg} / \mathrm{l}$ are more than the standard limit set by WHO $10.0 \mathrm{mg} / \mathrm{l}$. Chemical oxygen Demand is defined as the amount of a specified oxidant that reacts with the samples under controlled condition and is often using as a measurement of pollutants in natural water(AWWA, 1999). Chaurasia et al, 2013carried out pollution sources and water quality of River Mandakini at Chitrakoot, Analyzed the chemical oxygen demand in mandakini River Chitrakoot found COD ranged between 12-140 mg/l.

\subsection{Nitrate}

In the present study the nitrate content of water was found to be 0.09 to $6.47 \mathrm{mg} / \mathrm{l}$. The maximum value of $6.47 \mathrm{mg} / \mathrm{l}$ was observed at location $\left(\mathrm{R}_{19}\right)$ (Sagar , near railway station ) while the minimum value $0.09 \mathrm{mg} / \mathrm{l}$ was observed at, which is within permissible limit prescribed by WHO for drinking water standard. Srinivas et al, 2012 Studies on chemistry and Water Quality Index of ground water in Chincholi Taluk, Gulbarga district, Karnataka India, nitrate content was observed ranged from 26.2 to $122.0 \mathrm{mg} / \mathrm{l}$. Mahananda et al, 2010 monitoring of nitrate is important in drinking water because of health effects on human beings.

\subsection{Sulphate}

Sodium sulphate and magnesium sulphate exert a cathartic action in the human being and also surface is associated with respiratory illness. Therefore the recommended limit of sulphate content in drinking water is 200 to $250 \mathrm{mg} / \mathrm{l}$. The concentration of sulphate ranged from 0.001 to $186.3 \mathrm{mg} / \mathrm{l}$ in the study area. The maximum concentration of $(186.3 \mathrm{mg} / \mathrm{l})$ was detected at sampling station $\mathrm{R}_{27}$ (Guna District).The results obtained in the present study showed that sulphate content in all water samples were 0.001 to $1286.3 \mathrm{mg} / \mathrm{l}$ and is within permissible limit. Tripathi et al, 2016 studied the physicchemical studies on ground water and surface water in and around Katni city; Madhya Pradesh observed the sulphates values varied from 2.9 to $81.93 \mathrm{mg} / \mathrm{l}$.

\subsection{Phosphate}

In the present study the phosphate concentration varied from 0.001 to $2.83 \mathrm{mg} / \mathrm{l}$. The maximum concentration of phosphate $2.83 \mathrm{mg} / \mathrm{l}$ was detected at the location R10 (Jabalpur near S.B.I. Chaorha) while minimum concentration of phosphate was observed to be $0.001 \mathrm{mg} / \mathrm{l}$ at R12 (near Govt. P.G. college Siwani) sampling station. Santhi et al, 2014worked physico-chemical studies on water quality in thirukattlupallinearthanfavur and reported the phosphate content varied from 0.1 to $1.8 \mathrm{mg} / \mathrm{l}$

Table2. Average Physico-Chemical Characteristics of ground water in Residential Area of Two Different Zone of Central India

\begin{tabular}{|c|c|c|c|c|c|c|c|c|c|c|c|c|c|c|}
\hline S.N. & District & \begin{tabular}{|l|} 
Two \\
different \\
Zone of \\
Central \\
India \\
\end{tabular} & $\begin{array}{l}\text { Sampling } \\
\text { Code }\end{array}$ & $\begin{array}{l}\text { Temp } \\
\text { rature }\end{array}$ & $\mathrm{pH}$ & Turbidity & Hardness & TDS & DO & BOD & COD & Nitrate & Sulphate & Phosphate \\
\hline 1 & Rewa & $\begin{array}{l}\text { East } \\
\text { Zone }\end{array}$ & $\mathrm{R}_{1}$ & 29.37 & 6.50 & 2.37 & 228.33 & 345.33 & 4.68 & 3.60 & 5.37 & 4.17 & 5.53 & 0.187 \\
\hline 2 & Satna & \begin{tabular}{|l|} 
East \\
Zone
\end{tabular} & $\mathrm{R}_{2}$ & 29.23 & 7.40 & 2.00 & 468.33 & 312.00 & 3.56 & 7.43 & 5.70 & 5.13 & 9.90 & 1.867 \\
\hline 3 & Sidhi & \begin{tabular}{|l} 
East \\
Zone \\
\end{tabular} & $\mathrm{R}_{3}$ & 25.27 & 6.57 & 1.23 & 322.67 & 412.67 & 1.43 & 5.57 & 5.50 & 0.30 & 0.03 & 0.007 \\
\hline 4 & Singrauli & \begin{tabular}{|l|} 
East \\
Zone \\
\end{tabular} & $\mathrm{R}_{4}$ & 28.77 & 7.67 & 0.73 & 261.33 & 285.00 & 4.27 & 10.73 & 8.00 & 0.55 & 8.33 & 0.480 \\
\hline 5 & Shahdol & \begin{tabular}{|l} 
East \\
Zone \\
\end{tabular} & $\mathrm{R}_{5}$ & 28.53 & 6.77 & 0.27 & 191.67 & 252.67 & 4.03 & 3.10 & 7.13 & 0.82 & 4.97 & 0.026 \\
\hline 6 & Umaria & \begin{tabular}{|l} 
East \\
Zone
\end{tabular} & $\mathrm{R}_{6}$ & 26.07 & 7.70 & 2.40 & 215.33 & 328.00 & 3.10 & 4.53 & 6.33 & 3.47 & 170.00 & 0.167 \\
\hline 7 & Katni & \begin{tabular}{|l} 
East \\
Zone
\end{tabular} & $\mathrm{R}_{7}$ & 25.97 & 8.53 & 1.90 & 567.00 & 533.67 & 3.53 & 5.60 & 7.70 & 1.70 & 27.50 & 0.002 \\
\hline 8 & Panna & \begin{tabular}{|l} 
East \\
Zone
\end{tabular} & $\mathrm{R}_{8}$ & 27.93 & 7.10 & 4.77 & 362.33 & 341.00 & 3.03 & 3.70 & 12.83 & 0.80 & 10.03 & 0.029 \\
\hline 9 & Chhatarpur & $\begin{array}{l}\text { East } \\
\text { Zone }\end{array}$ & $\mathrm{R}_{9}$ & 29.43 & 7.23 & 2.57 & 229.67 & 321.67 & 5.47 & 6.27 & 7.40 & 0.53 & 5.37 & 0.130 \\
\hline
\end{tabular}


Physico-chemical Analysis and Mapping of Ground Water Quality in Residential Area of Two Different Zone of Central India

\begin{tabular}{|l|lll|l|l|l|l|l|l|l|l|l|l|l|l|}
10 & Jabalpur & $\begin{array}{l}\text { East } \\
\text { Zone }\end{array}$ & $\mathrm{R}_{10}$ & 28.87 & 7.67 & 2.97 & 312.00 & 333.00 & 3.20 & 3.40 & 6.30 & 5.47 & 8.60 & 2.833 \\
\hline 11 & Mandala & $\begin{array}{l}\text { East } \\
\text { Zone }\end{array}$ & $\mathrm{R}_{11}$ & 24.93 & 7.33 & 4.10 & 270.33 & 388.67 & 1.80 & 5.67 & 7.20 & 5.20 & 0.01 & 0.013 \\
\hline 12 & Dindori & $\begin{array}{l}\text { East } \\
\text { Zone }\end{array}$ & $\mathrm{R}_{12}$ & 28.20 & 6.53 & 1.23 & 368.67 & 332.33 & 4.13 & 3.07 & 6.33 & 2.87 & 14.73 & 0.001 \\
\hline 13 & Siwani & $\begin{array}{l}\text { East } \\
\text { Zone }\end{array}$ & $\mathrm{R}_{13}$ & 27.77 & 6.80 & 2.90 & 263.33 & 292.33 & 3.73 & 3.10 & 9.17 & 3.63 & 23.47 & 1.267 \\
\hline 14 & $\begin{array}{l}\text { Chhindwar } \\
\text { a East }\end{array}$ & $\mathrm{R}_{14}$ & 32.73 & 8.23 & 1.43 & 265.67 & 414.67 & 5.57 & 5.03 & 5.93 & 3.53 & 6.77 & 0.024 \\
\hline 15 & $\begin{array}{l}\text { Narsinghp } \\
\text { ur }\end{array}$ & $\begin{array}{l}\text { Zast } \\
\text { Zone }\end{array}$ & $\mathrm{R}_{15}$ & 25.93 & 7.23 & 0.10 & 236.00 & 321.00 & 4.63 & 4.50 & 3.50 & 7.80 & 12.30 & 0.008 \\
\hline 16 & $\begin{array}{l}\text { Hosangaba } \\
\text { East } \\
\text { Zone }\end{array}$ & $\mathrm{R}_{16}$ & 25.77 & 7.97 & 1.67 & 210.33 & 369.67 & 3.10 & 6.33 & 7.00 & 7.63 & 7.93 & 0.060 \\
\hline 17 & Betul & $\begin{array}{l}\text { East } \\
\text { Zone }\end{array}$ & $\mathrm{R}_{17}$ & 30.10 & 8.33 & 0.27 & 257.33 & 245.33 & 4.00 & 3.63 & 5.80 & 6.63 & 7.33 & 0.000 \\
\hline 18 & Damoh & $\begin{array}{l}\text { East } \\
\text { Zone }\end{array}$ & $\mathrm{R}_{18}$ & 27.97 & 6.67 & 2.13 & 312.33 & 286.67 & 3.50 & 6.43 & 7.80 & 5.43 & 7.80 & 0.037 \\
\hline 19 & Sagar & EasZone & $\mathrm{R}_{19}$ & 28.30 & 7.37 & 2.10 & 305.67 & 320.33 & 3.73 & 4.20 & 3.93 & 6.47 & 7.53 & 0.080 \\
\hline 20 & Bhopal & East & $\mathrm{R}_{20}$ & 27.67 & 6.87 & 2.33 & 214.67 & 323.00 & 2.97 & 3.63 & 8.50 & 5.23 & 5.53 & 0.047 \\
\hline
\end{tabular}

Table- 2 continue

\begin{tabular}{|c|c|c|c|c|c|c|c|c|c|c|c|c|c|c|}
\hline 21 & Gawaliar & $\begin{array}{l}\text { West } \\
\text { Zone }\end{array}$ & $\mathrm{R}_{21}$ & 26.90 & 7.60 & 1.87 & 736.67 & 280.00 & 5.13 & 15.17 & 37.00 & 2.12 & 38.67 & 0.241 \\
\hline 22 & Shivpuri & \begin{tabular}{|l|} 
West \\
Zone
\end{tabular} & $\mathrm{R}_{22}$ & 25.47 & 7.13 & 2.97 & 643.67 & 259.33 & 4.20 & 9.30 & 18.73 & 0.09 & 15.33 & 0.026 \\
\hline 23 & $\begin{array}{l}\text { Ashok } \\
\text { Nagar }\end{array}$ & $\begin{array}{l}\text { West } \\
\text { Zone }\end{array}$ & $\mathrm{R}_{23}$ & 27.87 & 8.20 & 1.77 & 500.33 & 276.33 & 3.90 & 13.67 & 11.50 & 0.42 & 36.33 & 0.036 \\
\hline 24 & Datiya & $\begin{array}{l}\text { West } \\
\text { Zone }\end{array}$ & $\mathrm{R}_{24}$ & 28.27 & 7.80 & 0.60 & 414.67 & 173.33 & 3.00 & 11.23 & 34.97 & 0.16 & 25.00 & 0.030 \\
\hline 25 & Muraina & $\begin{array}{l}\text { West } \\
\text { Zone } \\
\end{array}$ & $\mathrm{R}_{25}$ & 25.40 & 8.00 & 3.07 & 548.33 & 172.57 & 5.27 & 8.43 & 49.87 & 0.60 & 31.67 & 0.013 \\
\hline 26 & Bhind & $\begin{array}{l}\text { West } \\
\text { Zone } \\
\end{array}$ & $\mathrm{R}_{26}$ & 27.50 & 7.80 & 2.67 & 639.33 & 215.67 & 5.73 & 7.30 & 4.97 & 0.15 & 40.33 & 0.011 \\
\hline 27 & Guna & $\begin{array}{l}\text { West } \\
\text { Zone }\end{array}$ & $\mathrm{R}_{27}$ & 24.77 & 6.73 & 2.73 & 697.67 & 323.20 & 2.10 & 18.83 & 27.30 & 0.04 & 186.33 & 0.064 \\
\hline 28 & Tikamgarh & $\begin{array}{l}\text { West } \\
\text { Zone }\end{array}$ & $\mathrm{R}_{28}$ & 25.00 & 7.67 & 1.43 & 726.00 & 312.67 & 4.03 & 5.70 & 14.17 & 0.79 & 31.33 & 0.020 \\
\hline 29 & Vidisha & \begin{tabular}{|l|} 
West \\
Zone \\
\end{tabular} & $\mathrm{R}_{29}$ & 27.27 & 8.27 & 3.83 & 921.67 & 266.93 & 3.83 & 6.33 & 46.37 & 0.30 & 37.33 & 0.052 \\
\hline 30 & Raisen & $\begin{array}{l}\text { West } \\
\text { Zone }\end{array}$ & $\mathrm{R}_{30}$ & 27.10 & 7.83 & 1.80 & 730.00 & 212.07 & 3.40 & 9.77 & 32.90 & 0.46 & 27.00 & 0.021 \\
\hline 31 & Sihor & $\begin{array}{l}\text { West } \\
\text { Zone }\end{array}$ & $\mathrm{R}_{31}$ & 26.43 & 7.97 & 2.77 & 751.67 & 200.67 & 5.90 & 19.17 & 9.40 & 0.50 & 53.00 & 0.034 \\
\hline 32 & Rajgarh & $\begin{array}{l}\text { West } \\
\text { Zone }\end{array}$ & $\mathrm{R}_{32}$ & 30.60 & 8.20 & 3.87 & 683.33 & 243.43 & 3.63 & 5.20 & 31.80 & 0.73 & 41.00 & 0.036 \\
\hline 33 & Shajaput & $\begin{array}{l}\text { West } \\
\text { Zone }\end{array}$ & $\mathrm{R}_{33}$ & 25.17 & 7.60 & 2.43 & 329.00 & 219.00 & 3.33 & 5.33 & 15.27 & 0.53 & 13.00 & 0.013 \\
\hline 34 & Dewash & $\begin{array}{l}\text { West } \\
\text { Zone }\end{array}$ & $\mathrm{R}_{34}$ & 29.23 & 8.30 & 0.20 & 522.33 & 256.67 & 5.60 & 5.13 & 3.23 & 0.41 & 34.00 & 0.019 \\
\hline 35 & Ujjain & \begin{tabular}{|l|} 
West \\
Zone
\end{tabular} & $\mathrm{R}_{35}$ & 26.77 & 8.00 & 0.90 & 296.67 & 156.00 & 4.00 & 6.63 & 19.90 & 0.61 & 43.00 & 0.034 \\
\hline 36 & Ratlam & \begin{tabular}{|l|} 
West \\
Zone
\end{tabular} & $\mathrm{R}_{36}$ & 30.33 & 7.77 & 1.73 & 435.00 & 274.33 & 5.40 & 4.17 & 12.50 & 0.51 & 29.00 & 0.015 \\
\hline 37 & Indore & $\begin{array}{l}\text { West } \\
\text { Zone }\end{array}$ & $\mathrm{R}_{37}$ & 29.27 & 8.13 & 3.20 & 475.33 & 288.00 & 2.63 & 6.80 & 11.37 & 0.61 & 96.00 & 0.011 \\
\hline 38 & Khandawa & $\begin{array}{l}\text { West } \\
\text { Zone }\end{array}$ & $\mathrm{R}_{38}$ & 24.67 & 7.00 & 0.60 & 305.67 & 141.33 & 2.90 & 6.13 & 10.33 & 0.19 & 20.00 & 0.040 \\
\hline 39 & Burhanpur & $\begin{array}{l}\text { West } \\
\text { Zone }\end{array}$ & $\mathrm{R}_{39}$ & 29.43 & 6.50 & 1.07 & 356.67 & 246.33 & 4.63 & 4.50 & 4.77 & 0.32 & 26.00 & 0.020 \\
\hline 40 & Harda & $\begin{array}{l}\text { West } \\
\text { Zone }\end{array}$ & $\mathrm{R}_{40}$ & 28.00 & 7.53 & 0.27 & 264.33 & 160.67 & 3.13 & 5.00 & 7.20 & 0.09 & 7.00 & 0.008 \\
\hline
\end{tabular}




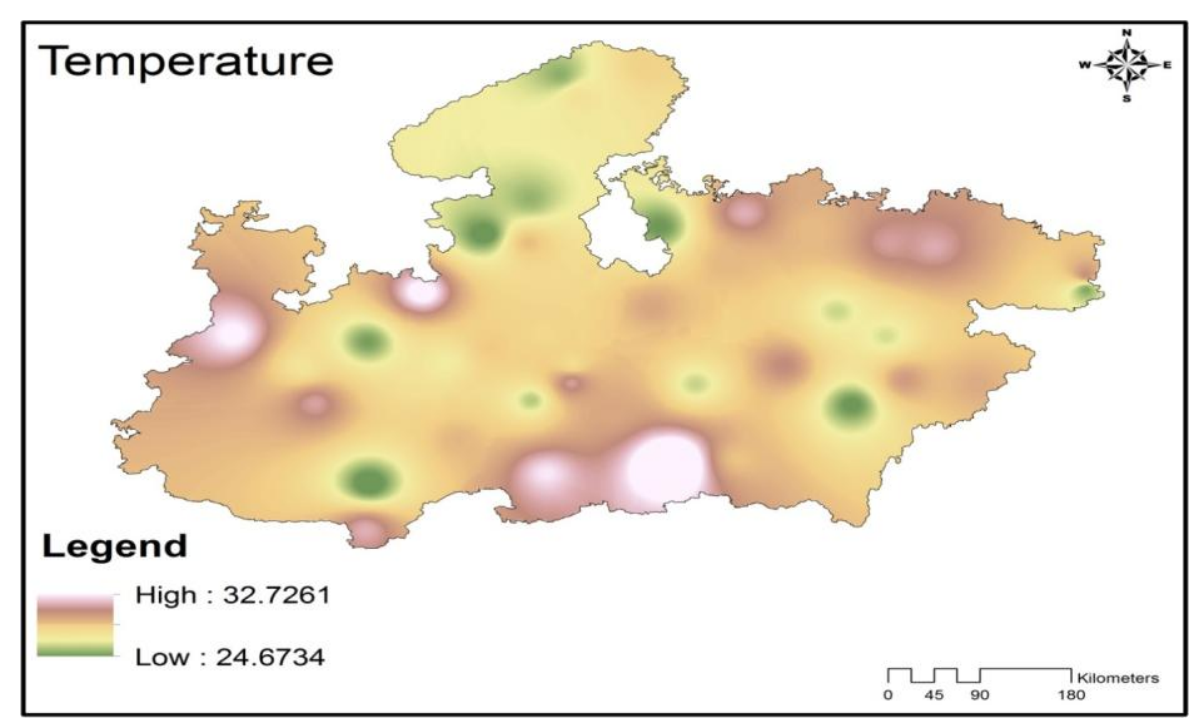

Figure2. Average Temperature of ground water in Residential Area of Two Different Zone of Central India

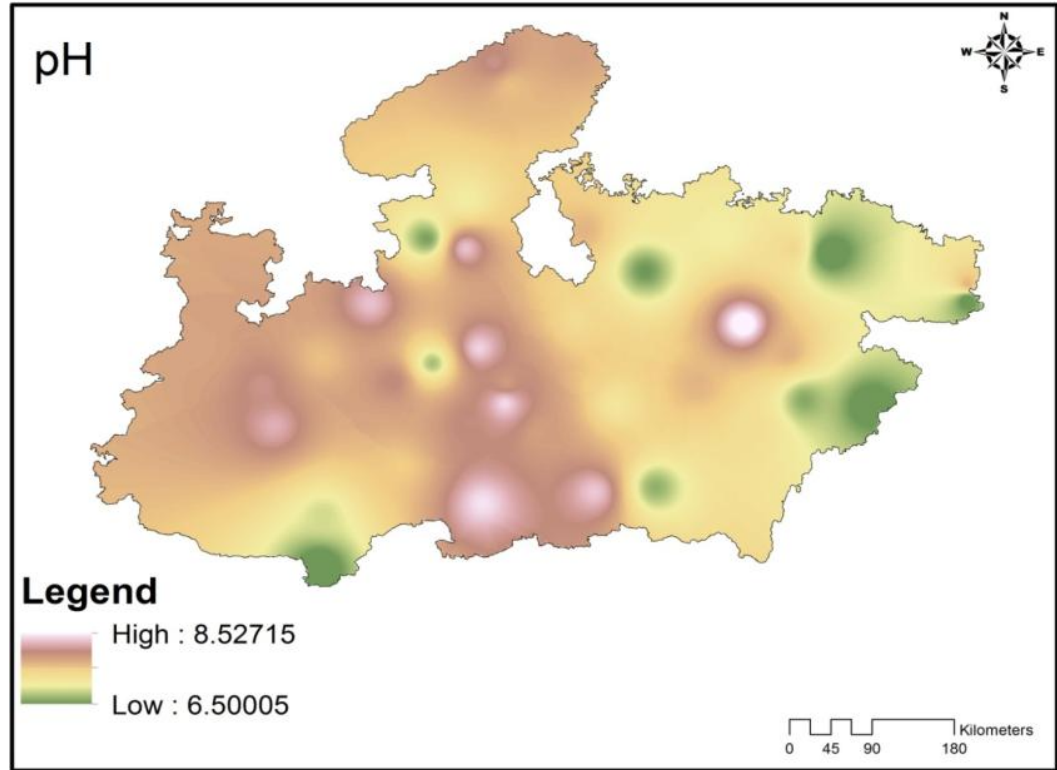

Figure3. Average pH of ground water in Residential Area of Two Different Zone of Central India

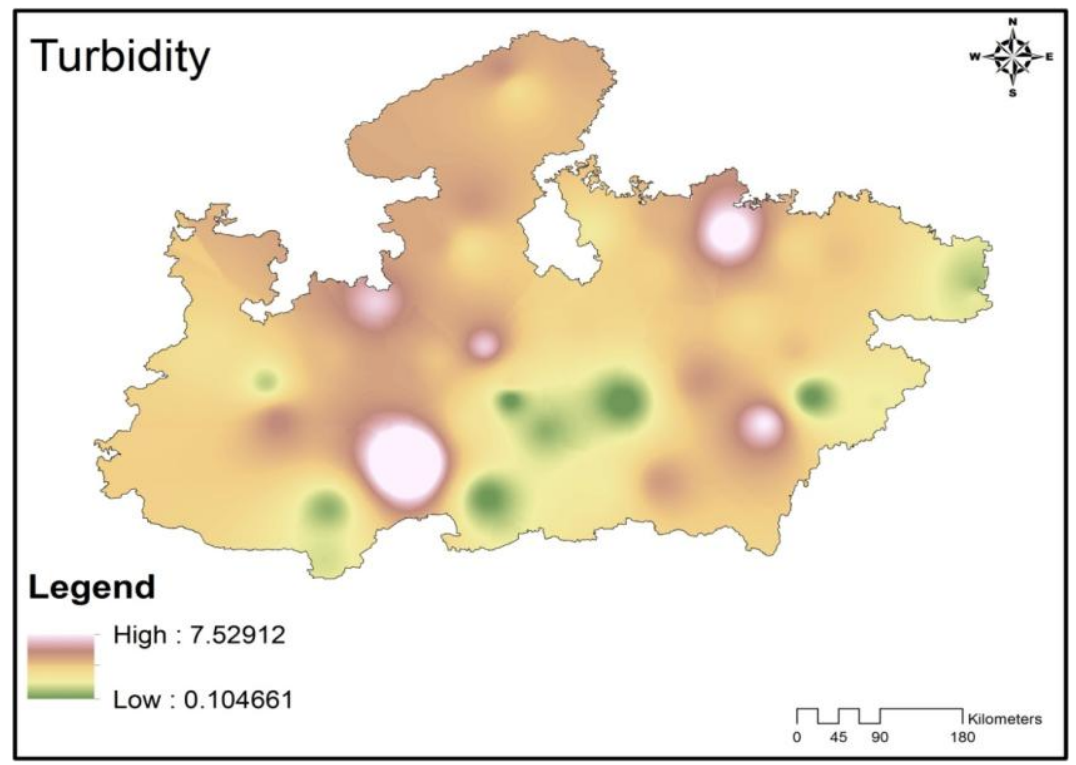

Figure4. Average Turbidity of ground water in Residential Area of Two Different Zone of Central India 


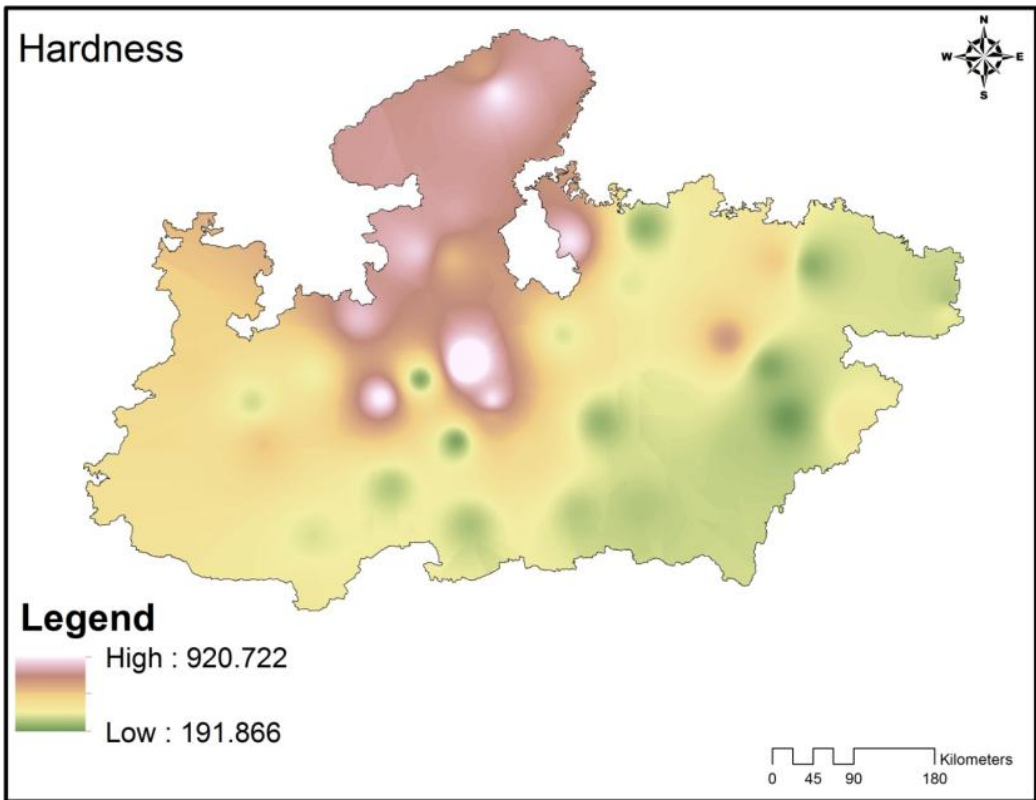

Figure5. Average Total hardness of ground water in Residential Area of Two Different Zone of Central India

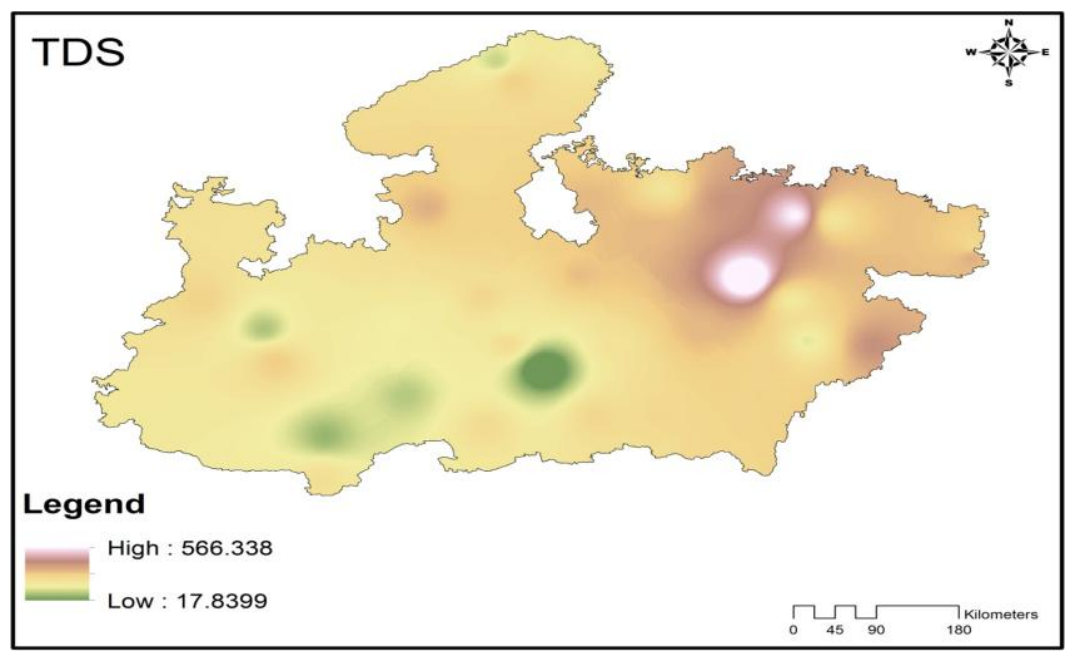

Figure6. Average T DS of ground water in Industrial Area of Two Different Zone of Central India

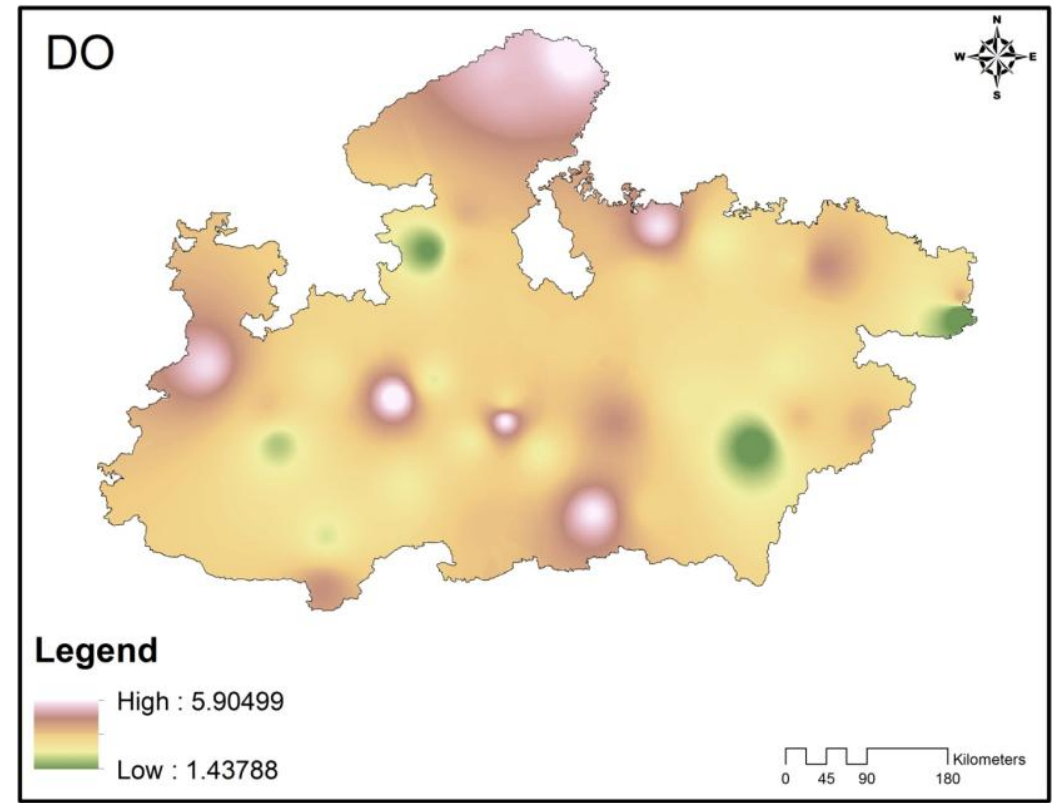

Figure7. Average DO of ground water in Residential Area of Two Different Zone of Central India 


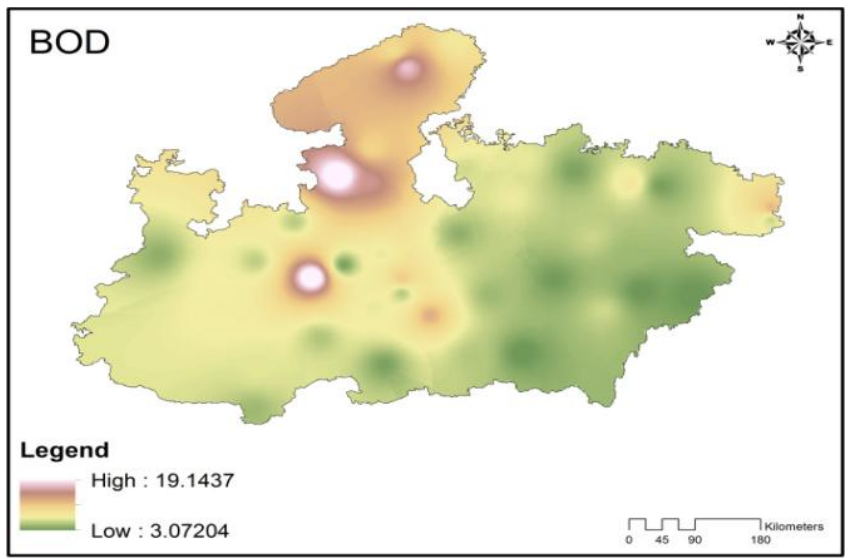

Figure8. Average BOD of ground water in Residential Area of Two Different Zone of Central India

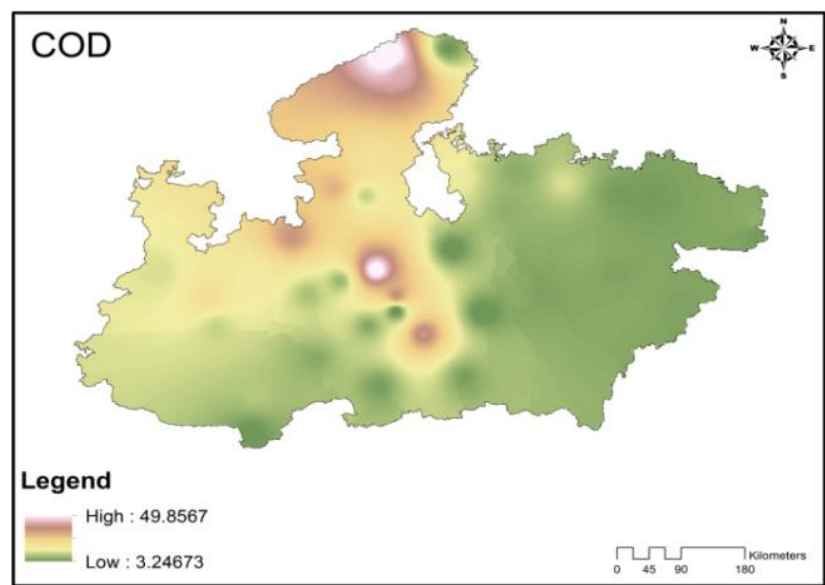

Figure9. Average COD of ground water in Residential Area of Two Different Zone of Central India

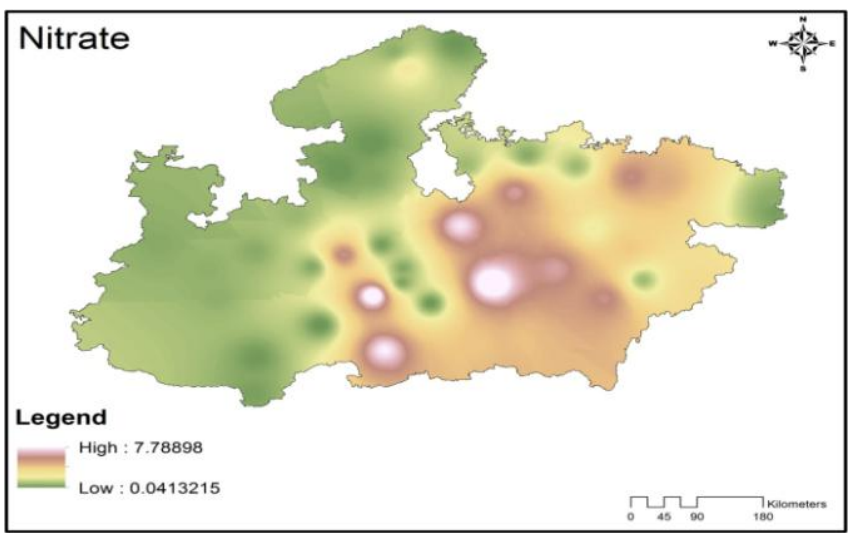

Figure10. Average Nitrate of ground water in Residential Area of Two Different Zone of Central India

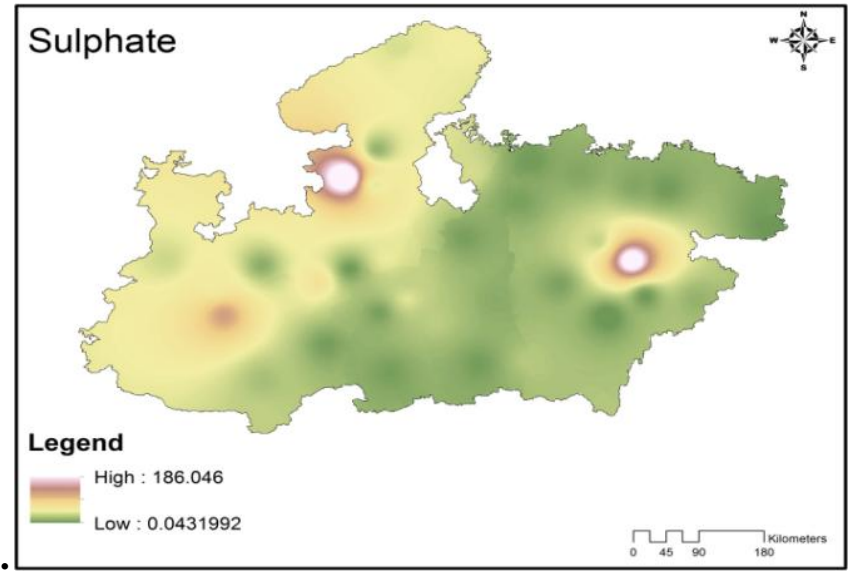

Figure11. Average Sulphate of ground water in Residential Area of Two Different Zone of Central India 


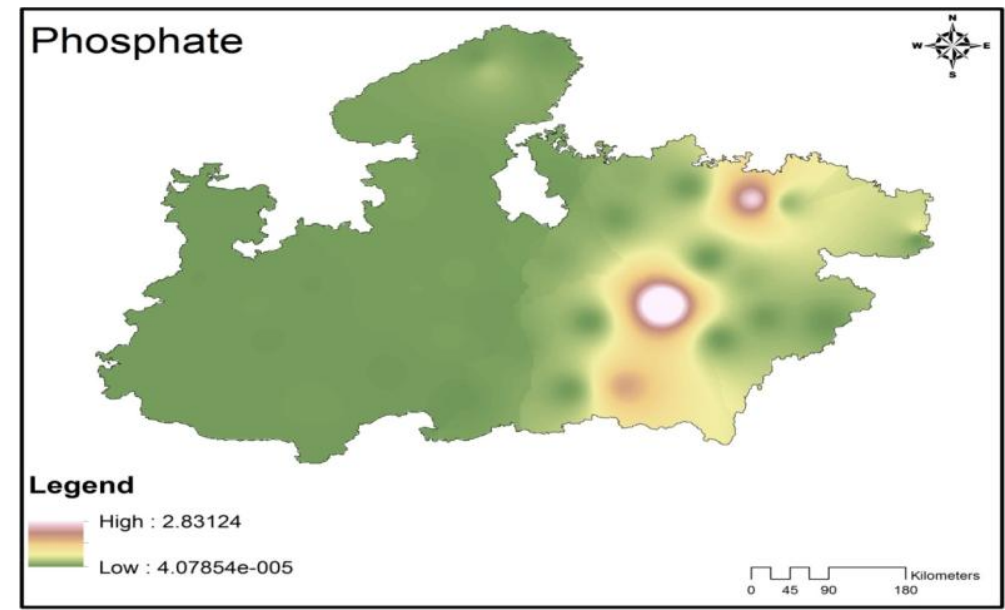

Figure12. Average Phosphate of ground water in Residential Area of Two Different Zone of Central India

\section{CONCLUSION}

The present study has been carried out to evaluate the quality of ground water in residential area of two different zones of central India. Forty sampling location were selected from study area. Sampling was done seasonally, during the study period (of the year 2013 to 2014). These samples were analyzed for eleven (Temperature, $\mathrm{pH}$, Turbidity, Total hardness, TDS, DO, BOD, COD, Nitrate, Sulphate and phosphate) physico-chemical parameters to evaluate their suitability for domestics applications. The results of the above work show that most of the physic-chemical parameters are well within the acceptable limit except some samples of TH, DO, BOD and phosphate in the study area, during the study period mostly exceeded the recommended value of WHO. The chemical oxygen demand concentration exceeds the permissible limit in sixteen samples locations. It indicates that the extent of pollution occurred due to the urbanization and other anthropogenic activities increased human interventions in the ground water quality. Ground water pollution in the studied area showed is controlled by the proper environment management plan to maintain proper health conditions.

\section{ACKNOWLEDGEMENT}

The authors were grateful to University Grant Commission (No.F41-855/2012 (SR), New Delhi for the provision of financial support to carry out this research work.

\section{REFERENCES}

Arya, S., Kumar, V., Minakshi and Dhaka, A. (2011). Assessment of Underground Water Quality: International Multidisciplinary Research Journal, v. 1, pp. 11-14.

Chaurasia, Sadhana and Rajkaran, (2013).Pollution Sources and Water Quality of River Mandakini at Chitrakoot, IJEP, v.33, pp. 969-977.

Calamari, D. and Naeve, H.(1994).Review of Pollution in the African Aquatic Environment, Committee for Inland Fisheries of Africa (CIFA) Technical Paper No. 25, FAO, Rome, 118.

Dwivedi, A.P., Dwivedi, A., Awasthi, Ashwani Kumar and Tripathi, I.P. (2016). Quality of Ground water used for Drinking in Orai, District- Jalaun, Uttar Pradesh, international Journal of Information Research and Review v.03, pp.1915-1920.

Eo. A. Aina and Adedipe, N. O. (1996).Water Quality Monitoring and Environmental Status in Nigeria, FEPA Monograph 6, FEPA, Abuja, Nigeria, 239.

Gupta, L. N. and Gupta, G.S. (2010).Valuation of Ground Water Quality around Kamadgiri Parikrama at Chitrakoot, IJEP, v. 30, pp. 104- 109.

Garge, D. K., Pant, A.B., Agrawal, M., Goyal, B. and R.N. (1990).Seasonal Variation in Ground water Quality in Roorki City, Indian J. Env. Prot., v.10, pp. 673-676

Karunakaran, K., Thamilarasu, P. and Sharmila, R. (2009). Statistical Study on physico-chemical Characteristics of Ground Water in and Around Namakkal, Tumilnadu, India. Journal of Chemistry, v.6, pp. 909- 914.

Mahananda, M. R., Mohanty, B.P., and Benera, N. R., (2010). Physico-chemical Analysis of Surface and Ground water of BargarhDistict, orissa, IJRRAS, v.2, pp. 284-293.

Okoh,A. I.,Odjadjare, E. E.,IgbinosaE.O. and Osode, A. N.(2007).Waste Water Treatment Plants as a Source of Microbial Pathogens in the Receiving Watershed, Afr. Journal Biotech, v.6,pp.2932 - 2944. 
Rajmohan, N., Elango, L. and Elampooranam, T. (1997). Seasonal and spatial variation in Magnesium and Chloride concentration in Ground water of Nagar Quad -E-Milleth District in Tamilnadu, Indian J. Env. Prot., v.17, pp. 448-453

Sunitha, V., Sudarshan V., and Reddy, B. Rajeswara (2005) Hydro Geochemistry of Ground Water, Gooty Area, Anantpur District, Andhra Pradesh, India. Poll. Res, v. 24, pp. 217 - 224.

Santhi, S., kalainvani, D., Mahalakshmi, A. and S. Amala, (2014). Physico-chemical Studies on Water Quality in ThirukattupllinearThanjavur, IJEP, v. 34, pp. 765-768.

Singh, R.P., Chauhan, B.S., Swaroop D. and Yadav, Y.S. (2000).Seasonal Variation in Ground water of Agra City, Indian J. Env. Prot., v. 42, pp. 59-69.

Standard Method for the Examination of Water and Waste Water (20th Edition) APHA, America Water Works Association (AWWA) and Water Work Environment Federations, Washington. (1999), pp. 1325.

Shrivastav, K.B.L., Mishra, S.P. and Manlick, N. (2014), Ground Water Quality Assessment of Birsinghpur Area, Satna District, Madhya Pradesh, India. Journal of Innovative Trends in Science, Pharmacy and Technology, v.1, pp. 125-132

Sharma, Deepshika (2014). A Physico-chemical Analysis and Management of Ground Water Bodies from Twenty Locations of Jodhpur District, Journal of Applicable Chemistry, v. 3 , pp. 764- 768.

Srinivas, K. and Srinivas, Padaki (2012) Studies on chemistry and Water Quality Index of ground water in ChincholiTaluk, Gulbarga district, Karnataka India. International Journal of Environmental Science, v.2, pp. 1154-1160.

Santhi, S., Kalaivani, D., Mahalakshmi A. and Amala, S. (2014). Physico- chemical Studies on water quality in TtirukattupallinearThanjavur, IJEP v.34, pp.765-768

Tripathi, I.P., Dwivedi, A.P.,Kumar, M. Suresh and Gautam S.S.(2014).Physico-Chemical Parameters and Correlation Coefficients of Ground Waters of Shahdol District, AARJMD, v. 1, pp. 178-200.

Tripathi, Indra Prasad, Dwivedi, Arvind Prasad and TiwariVipin (2015) Qualityand Assessment of Ground water in Satna, Madhya Pradesh, Journal of Applicable Chemistry, v.4, pp 615-623.

Tripathi, Indra Prasad, Dwivedi, Arvind Prasad and Sahu, Rinku, (2016). Physico-chemical Studies on Ground water and Surface water in and Around Katni City, Madhya Pradesh, International Journal of Information research and Review, v. 3, pp. 1722-1729.

Tripathi, I.P.,Kumar,M. Suresh and Dwivedi, A.P.(2013).Characterization of Diffuse Chemical Pollution in Satna District of Vindhya Region, India, International Research Journal of Environment science, v. 2 , pp.46-60.

WHO (1984).Guideline for Drinking Water Quality, Recommendation, World Health organization Geneva, v. 2.

Citation: Arvind Prasad Dwivedi \& Indra Prasad Tripathi, "Physico-chemical Analysis and Mapping of Ground Water Quality in Residential Area of Two Different Zone of Central India", International Journal of Advanced Research in Chemical Science (IJARCS), vol. 4, no. 10, pp. 15-25, 2017. http://dx.doi.org/ 10.20431/ 2349-0403.0410002

Copyright: (C) 2017 Authors. This is an open-access article distributed under the terms of the Creative Commons Attribution License, which permits unrestricted use, distribution, and reproduction in any medium, provided the original author and source are credited. 